\title{
Possible AVT Involvement in Regulation of Body Water Balance during the Incubation Period in the Chabo Hen
}

\author{
Kiyoshi Shimada and Noboru Saito \\ Laboratory of Animal Physiology, School of Agricultural Sciences, \\ Nagoya University, Nagoya-shi 464-01
}

\begin{abstract}
Plasma concentrations of arginine vasotocin (AVT), pituitary prolactin messenger RNA (PRL mRNA) and weights of ovary and oviduct were measured at different reproductive stages in the Chabo hens. Concentrations of plasma AVT dropped significantly at the laying stage but increased at 1-week of incubation stage and was sustained during the whole incubation period. The concentration decreased markedly at the brooding stage of rearing chicks. At the laying stage weights of ovary and oviduct were the highest while it remained at other stages. Pituitary PRL mRNA expression was high during the incubation period as previously observed in the Chabo hens. The present results may indicate the sustained level of plasma AVT is involved, at least in part, in the regulation of body water balance.
\end{abstract}

(Jpn. Poult. Sci., 34 : 169-174, 1997)

Key Words : AVT, prolactin, incubation, chabo, water balance

\section{Introduction}

Arginine vasotocin (AVT) is a neurohypophysial hormone that plays pivotal roles in the regulation of oviposition and osmolality in birds. This avian neurohypophysial hormone is unique because it possesses both oxy tocic and antidiuretic actions, whereas in mammals each of them is brought about by specific hormones, oxytocin and vasopressin, respectively. In regard to antidiuretic AVT action, several studies experimentally manipulated have been reported. Hypertonic saline $(1.0 \mathrm{M} \mathrm{NaCl})$ infusion causes an immediate increase in plasma concentration of AVT for water resorption through the kidney and thus retains body water in the chicken (KoIKE et al., 1986 ; SHIMADA et al., $1991 \mathrm{~b}$ ). However, there has been little information on AVT action under more physiological conditions. During the course of our work in relation to broodiness in the Chabo hens we have observed these birds drink surprisingly less water and blood hematocrit rises during the incubation period (ZADWORNY, et al., 1988). Under such a special but physiological condition AVT must fluctuate in relation to water balance. Furthermore, prolactin (PRL) released enormously during the incuba-

Received October. 8, 1996 Accepted December. 18, 1996

Correspondence and reprint requests should be addressed to Dr. Kiyoshi SHIMADA, Laboratory of Animal Physiology, School of Agricultural Sciences, Nagoya University, Chikusa, Nagoya 464-01, Japan, Tel. 052-789-4065, Fax. 052-789-4012, E. mail : g 44500 a@nucc.cc.nagoya-u.ac.jp 
tion period may be associated with AVT release because in mammals neurohypophysial hormones are implicated in the regulation of PRL release (MAT. THEWS and PARRot, 1994). Such background information prompted us to measure plasma AVT concentrations responsible for osmoregulation in relation to broodiness in Chabo hens.

\section{Materials and Methods}

Twenty-five adult Chabo hens were used in this experiment. They were assigned at random in a group of two hens to each floor pen equipped with nest boxes. In each group a rooster was provided. They were maintained on $15 \mathrm{hr}$ light and $9 \mathrm{hr}$ darkness (lights-on from $7: 00$ to $22: 00$ at intensity of 200 lux). As the hens started laying, eggs were recorded, nest boxes were checked four times daily between $8: 00-21: 00 \mathrm{hr}$, and the presence of a bird in the nest boxes was recorded. The hens were allowed to accumulate, incubate and hatch their clutch of eggs and then brood the chicks for 1 week following the hatch. Chicks were allowed free access to commercial chicken ration and a source of water that was inaccessible to the criteria described previously (ZADWORNY et al., 1988). Hens were decapitated and tissues and plasma were collected from hens in the following reproductive stages : (1) prelaying hens that did not lay eggs under $15 \mathrm{~L} 9 \mathrm{D}$ lighting regime $(\mathrm{n}=4)$, (2) laying hens that had laid at least five eggs within the proceeding 7 days $(n=4),(3)$ hens which had incubated for 1 week $(n=5),(4)$ for 2 weeks $(n=4),(5)$ for 3 weeks $(n=4)$ that exhibited persistent nesting activity and had hatched newly chicks, and (6) brooding hens $(n=4)$ that were rearing their chicks 1 week after hatching of their clutch. All collections of blood and tissues were done at 13:00. All times of egg laying in the laying hens were in the morning. Body weight and weights of the ovary and oviduct were recorded. Anterior pituitary glands were removed, placed into sterile microcentrifuge tubes, snap-frozen in liquid nitrogen, and stored at $-80^{\circ} \mathrm{C}$. Blood samples were collected from the carotid artery into heparinised test tubes, centrifuged, and the plasma was stored at $-20^{\circ} \mathrm{C}$ until use for RIA.

\section{RNA Extraction, RNA Dot Hybridization and RIA}

Total RNA was extracted (Сномсzynski and SACCHI, 1987), five $\mu \mathrm{g}$ of glyoxylated RNA was applied to the nitrocellulose membrane using a dot manifold apparatus according to the instructions of the manufacturer (BRL, Inc., Gaithersburg, MD). Preparation of ${ }^{32} \mathrm{P}-\mathrm{dCTP}$ labeled chicken prolactin (PRL) cDNA and dot hybridization procedures were same as described previously (SHIMADA et al., 1991 a). Identification of PRL specific mRNA signals were determined on 3 different dilutions of total RNA from 5 to $1.25 \mu \mathrm{mg}$. Plasma concentration of AVT was determined by RIA as described previously (SHIMADA et al.; 1986). RIA data are presented as means \pm SEM. Comparisons between means were made by Duncan's new multiple range test after analysis of variance. Differences were considered significant at the level of $\mathrm{P}<0.05$.

\section{Results}

Figure 1 shows a typical example of autoradiogram of PRL mRNA during the 
different reproductive stages in the anterior pituitary gland. Markedly hybridizable signals were observable when the Chabo hens displayed incubation behavior (Figure 1), while the signals were found to a lesser extent when they were in the stages of nonlaying, laying and brooding. Figure 2 shows changes in weights of ovary and oviduct during the reproductive stages. The ovary and oviduct weight were the largest at the laying stage among the stages. In Figure 3 shown were changes in plasma concentration of AVT during the reproductive stages. Plasma AVT concentration in the nonlaying stage significantly decreased when hens were in the laying stage but they were restored to the level of the nonlaying stage when hens were in the incubating stage. High concentration was maintained throughout the incubation period as well as at the time of hatching. When hens were in the brooding stage, AVT level markedly decreased.

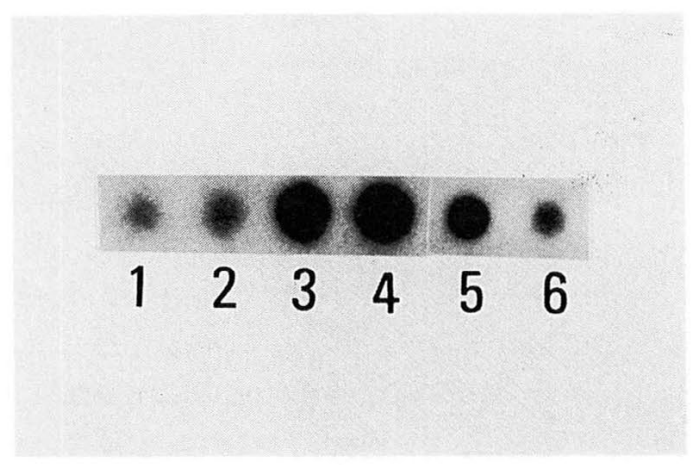

Fig. 1. PRL mRNA dot-blot analysis of total RNA (5 $\mu \mathrm{g})$ prepared from pituitary gland of chickens at different reproductive stages. The numbers indicate the reproductive stages, 1 , pre-laying ; 2 , laying ; 3 , day 7 of incubation ; 4 , day 14 of incubation ; 5 , hatching ; 6 , rearing.

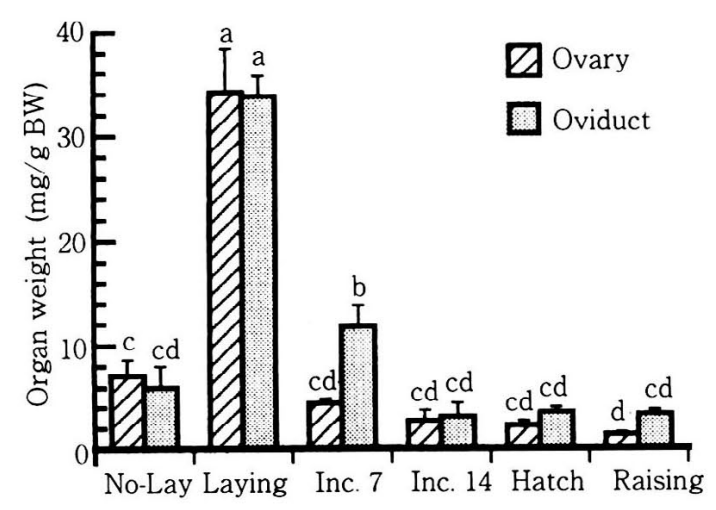

Fig. 2. Changes in weights of ovary and oviduct $(\mathrm{mg} / \mathrm{g}$ of body weight) at different reproductive stages (see Material and Methods). Means \pm SEM $(\mathrm{N}=4-5)$. Means with different letters are significantly different from each other $(\mathrm{P}<0.05)$. 


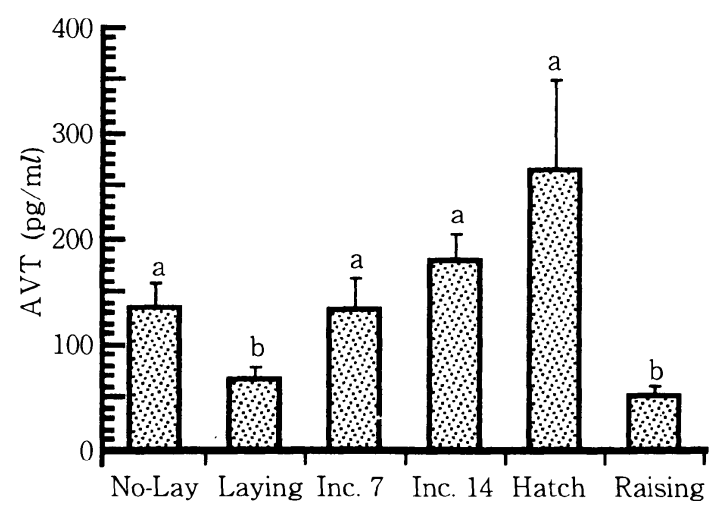

Fig. 3. Changes in plasma AVT concentrations at different reproductive stages. Means $\pm \operatorname{SEM}(\mathrm{N}=4-5)$. Means with different letters are significantly different from each other $(\mathrm{P}<0.05)$.

\section{Discussion}

The present study clearly characterized the different reproductive stages including the 3-weeks of incubation period in terms of ovary and oviduct weights and specific PRL mRNA expression. Although PRL concentrations in plasma and pituitary gland were not measured in this study, several previous reports including us demonstrated highly positive correlation among PRL mRNA, pituitary PRL content and plasma PRL concentration in particular reference to broodiness in the chicken (Shimada et al., 1991 a ; TAlBot et al., 1991 ; Kansaku et al., 1994). On the contrary, negative correlation between ovarian activities and pituitary PRL activity has also been documented as observed in the studies (SAEKI and TANABE, 1955 ; ZADWORNY, et al., 1988).

Incubation behavior of the chicken is characterized with sitting on the eggs in the nest over $95 \%$ time of day for 3 weeks and marked reduction in time spent drinking and feeding (SAVORY, 1979 ; LEA, et al., 1981 ; KONO, et al., 1985 ; ZADWORNY, et al., 1985 ; ZADWORnY, et al., 1988). This drastic shift of behavior is largely provoked by PRL. Reduction of water intake during the incubation period is about $80 \%$ of that during the laying period and significant increase in the percentage of red blood cells from 29.2 and 32.7 may be reflected due to limit of water intake during the incubation period (ZADWORNY, et al., 1988). The present study demonstrated that plasma AVT concentration during the incubation period was higher than that during the laying period. This inverse relationship between water intake and plasma AVT concentrations in the two stages may suggest that AVT is responsible for antidiuretic action to maintain body water. These results indicate drastic and severe changes in water retention and osmolality during the incubation period. Since PRL is also implicated in participation of osmoregulation in birds (ENSOR, 1978), there may be some interrelationship between AVT and PRL secretion. Although it might be indirect via osmoregulation, AVT may be involved for PRL secretion. In mammals, vasopressin (ADH) is suggested as a 
stimulator for PRL release (LiU and Jonathan, 1994 ; Matthews and Parrot, 1994). In aves, there has been no substantial evidence in this regard but further studies may be promising.

\section{Acknowledgments}

The authors would like to express their gratitude to Drs H. Artman and D.A. FISHER (UCLA) for a gift of AVT antiserum (R 70), to Dr. K. NAKASHIMA (Mie University) for a gift of chicken PRL cDNA and to the Radioisotope Center of Nagoya University for use of the Radioisotope facilities. This study was supported partly by grant-in-aid from Ministry of Education of Japan, Monbusho International Scientific Research Program (Joint-Research ; No. 0704419) to KS.

\section{References}

Chomczynski, P. and N. SACchi (1987). Single step method of RNA isolation by acid guanidium thiocyanate-phenol-chloroform extraction. Analytical Biochemistry, 162 : 156-159.

Ensor, D.M. (1978) 'Comparative Endocrinology of Prolactin'. Chapman and Hall, London.

Kansaku, N., K. Shimada, O. Terada and N. Saito (1994) Prolactin, growth hormone and luteinizing hormone- $\beta$ subunit gene expression in the cephalic and caudal lobes of the anterior pituitary gland during embryogenesis and different reproductive stages in the chicken. General and Comparative Endocrinology, $96: 197-205$.

Koike, T.I., H.L. Neldon, D.W. Mckay and P.L. Rayford (1986) An antiserum that recognizes mesotocin and isotocin: development of homologous radioimmunoassay for plasma mesotocin in chickens (Gallus domesticus). General and Comparative Endocrinology, 63 : 93103.

Kono, T, T. Kuwayama, H. Itoh and K. Ichinoe (1985) Nesting behavior and changes is plasma concentrations of progesterone, testosterone, and estradiol in the native Japanese breed of chicken, Gifujidori (Gallus domesticus). Japanese Poultry Science, 22 : 64-72.

Lea, R, A.S.M. Dods, P.J. Sharp and A. Chadwick (1981) The possible role of prolactin in the regulation of nesting behaviour and the secretion of luteinizing hormone in broody bantams. Journal of Endocrinology, $91: 89-97$.

LiU, J.W. and B.N. Jonathan (1994) Prolactin-releasing activity of neurohypophysial hormones : structure-function relationship. Endocrinology, 134:114-118.

Matthews, S.G. and R.F. PARROT (1994) Centrally administered vasopressin modifies stress hormone (cortisol, prolactin) secretion in sheep under basal conditions, during restraint and following intravenous corticotrophin-releasing hormone. European Journal of Endocrinology, $130: 297-301$.

SAEKI, Y. and Y. TANABE (1955) Changes in prolactin content of fowl pituitary during broody periods and some experiments on the induction of broodiness. Poultry Science, 34 : 909-919.

SAvory, C.J. (1979) Changes in food intake and body weight of bantam hens during breeding. Applied Animal Ethology,5 : 283-288.

Shimada, K., H. Ishida, K. Sato, K. Seo and N. Matsui (1991 a) Expression of prolactin gene in incubating hens. Journal of Reproduction and Fertility, 91 : 147-154.

Shimada, K., H.L. Neldon and T.I. Kolke (1986) Arginine vasotocin (AVT) release in relation to uterine contractility in the hen. General and Comparative Endocrinology, $64: 362-367$.

Shimada, K., H.L. Neldon and T.I. KoIKe (1991 b) Effects of saline infusion on plasma levels of vasotocin (AVT) and mesotocin in laying hens. Japanese Poultry Science, 28 : 214-219.

Talbot, R.T., M.C. Hanks, R.J. Sterling, H.M. SANG and P.J. Sharp (1991) Pituitary prolactin messenger ribonucleic acid levels in incubating and laying hens : effects of manipulating plasma levels of vasoactive intestinal poly peptide. Endocrinology, $129: 496-502$.

Zadworny, D., K. Shimada, H. Ishida and K. Sato (1988) Changes in plasma levels of prolactin and estradiol, nutrient intake, and time spent nesting during the incubation phase of broodiness 
in the Chabo hen (Japanese bantam). General and Comparative Endocrinology, 71 : 406-412.

ZADWORNY, D., J.S. WALTON, and R.J. ETCHES (1985) The relationship between plasma concentrations of prolactin and consumption of feed and water during the reproductive cycle of the domestic turkey. Poultry Science, $64: 401-410$.

\title{
チャボの就巣時における体内水分平衡に対する \\ AVT の関与の可能性
}

\author{
島田清司・斉藤 昇 \\ 名古屋大学農学部資源生物環境学科動物機能制御学講座 \\ 名古屋市千種区不老町 464-01
}

就巣性チャボの（成鳥雌）の異なる繁殖期（1. 産卵前 休産期 ; 2 . 産卵期 ; 3. 抱卵開始後一週間 ; 4. 抱卵開始 後二週間 ; 5 . 雛の粰化当日 ; 6. 育雊開始後一週間) にお ける血中アルギニンバソトシン (AVT) 濃度, 卵巣と卵 管重量および下垂体のプロラクチン mRNA 量の測定を 行った。

Ifll中 AVT 濃度は RIA により，プロラクチン mRNA 量はドットブロットハイブリダイゼーションにより定量 した。血中 AVT 量は, 休産期から産卵期にかけて著し く減少したが, 抱卵期には再び増加し高濃度に維持され た。篗の餒化当日も血中 AVT 濃度が高濃度であったが
育雅開始後一週目には減少した。卵栄と卵管重量は産卵 期に最大值であったが，抱卵期を含めその他の時期では 著しく低かった。下垂体プロラクチン mRNA 発現は抱 卵期と捊化当日は著しく高かったが，その他の時期では 低かった。就巣抱卵行動に伴う飲水量の低下や血中へマ トクリット值の増加というこれまでの報告とこれらの結 果を合わせると, AVT は抱卵期における体内水分維持 の調節に関与していると考えられる。

（家昺会誌，34:169-174, 1997） キーワード : バソトシン, プロラクチン, 就巣, チャボ, 水分平衡 